\title{
CESIJAS TIESISKĀ REGULĒJUMA PILNVEIDOŠANAS NEPIECIEŠAMĪBA
}

\section{REGULATION OF ASSIGNMENT (CESSIŌ) REQUIRES IMPROVEMENTS}

\author{
Kalvis Torgāns, Dr. habil. iur.
}

Latvijas Universitātes Juridiskās fakultātes

Civiltiesisko zinātnu katedras profesors

\section{Summary}

The business practices both in Latvia and worldwide show that the assignment (in Latin, cessiō), which, undoubtedly, has its good qualities, may also harm the rule of law and the security of civil circulation if it is used by "skilled machinators" or even criminals. The contractual assignment is an agreement between two private persons, but often affects not only the interests of the debtor, but also the interests of other (third) parties. The draft regulation of the EU published in 2018 has raised the issue of improving the assignment in the laws of the Member States.

Atslēgvārdi: cesija, prasijums, maksātnespēja, trešās personas, kauzāls darījums

Keywords: assignment, cession, claim, insolvency, third persons, causal transaction

\section{Ievads}

Gan pasaules, gan Latvijas biznesa prakse rāda, ka cesija, kurai neapšaubāmi ir labas īpašības, tomēr var nodarìt arī l̦aunumu tiesiskumam un civiltiesiskās apgrozības drošỉbai, ja to izmanto "prasmīgi mahinatori” vai pat noziedzīgas personas. Lìgumiskā cesija gan ir divu privātpersonu darỉjums, taču bieži vien skar ne tikai parādnieka, bet arī citu (trešo) personu intereses. 2018. gadā publicētais Regulas projekts ir aktualizējis jautājumu par cesijas regulējuma pilnveidošanu dalỉbvalstu likumos.

\section{Prasījums kā apgrozības prece}

Cesija ir prasījuma pāreja no viena kreditora citam pēc tiesiska darījuma, likuma vai tiesas sprieduma (CL 1793. p.). Cesijas rezultātā mantisks prasījums, kuram ir zināma vērtība, līdzīgi kā ķermeniskai lietai, pāriet pie cita tiesību subjekta, un šāda civiltiesiskā apgrozība var turpināties arī vairākas reizes. Kreditoru, kura prasijums pāriet uz jauno kreditoru, sauc par cedentu, bet jauno kreditoru par cesionāru. 
Prasījums ir atzìts par preci, kas ir apgrozības spējīga. Vasilijs Sinaiskis norādījis: "Gandrīz visas saistību tiesības [prasījumu nozìmē - autora piezīme] pirms to izpildīšanas kḷūst apgrozībā par ekonomiskām vērtībām, tādējādi pavairojot sabiedrībā apgrozības līdzekḷus. Tāpēc cesija vērtīga arī no sociāli-ekonomiskā viedokḷa."

Apgrozībā ir nonācis faktiski tikai pienākums dot kaut kādu mantisku labumu, nevis pats mantiskais labums, taču tāpat ir ar obligācijām, akcijām, vekseḷiem civiltiesiskajās, it sevišķi komerciālajās, attiecībās šāda bezķermeniska, varbūt var teikt, virtuāla, bagātību aprite ir kḷuvusi par pierastu lietu gan kreditēšanas, gan faktoringa, saistību pastiprināšanas un citās attiecībās. Tas var radìt ātri brūkošas finanšu piramīdas, kā rādīja bankas Lehman Brothers International Europe un vairāku citu banku mākslīgi uzpūstās varenības sabrukums, taču kapitālisma pasaule šo abstrakto mantas simbolu apriti netaisās aizliegt vai būtiski ierobežot. Gluži pretēji, ES tiesību aktos par cesiju prasījums tiek traktēts kā relatīvi no naudas un ķermeniskām lietām nošķirts īpašuma tiesību objekts. Ir parādījies jauns termins "vērtspapīrošana"2 (angḷu val. - securitisation, no - securities ${ }^{3}$ ), ar ko apzīmē agrāk apjoma ziṇā nepieredzētu tirdzniecību ar vērtspapīriem (securities), kuru segumu ar mantiskām vērtībām nav iespējams ticami izmērīt. Prakse rāda, ka vērtspapīrošana gan ir saistīta ar paaugstinātu risku, bet bieži nes lielu pel̦nu.

Cesija bieži parādās arī Latvijas tiesu praksēe diemžēl dažkārt radot sarežgìitu attiecību virknējumu, kur ir grūti pārbaudìt, vai cesija patiesi notikusi un kādi bijuši tās nosacījumi.

\section{Cesijas izkropḷojumi, kas atklājas Latvijas tiesu praksē}

Visspilgtāk cesijas izkropḷojumi parādās maksātnespējas un tiesiskās aizsardzības (TAP un ĀTAP ${ }^{4}$ ) procesos, kuros pret grūtībās nonākušu komersantu tiek pieteikti kreditoru prasījumi, kurus dažādi kreditori it kā ieguvuši cesijas ceḷā un kuri konkurē ar pēdējā laikā nodibinātu un ar pierādijjumiem apstiprinātu saistību izpildes prasījumiem.

Ekspertu komisija, kas Tieslietu padomes uzdevumā analizēja tiesu nolēmumus maksātnespējas un TAP procesos, lietā par SIA "Gabriels" (turpmāk -“G”) TAP pieteikumu ${ }^{5}$ konstatēja vairākas secīgas cesijas, kas teorētiski var norādīt uz netipisku darījumu ķēdi, un nevar izslēgt procesuālo tiesību negodprātīgu izmantošanu, leǵitimizèjot fiktīvus prasījumus ar tiesas nolēmumiem citās lietās (par saistību izpildi brīdinājuma kārtībā), ko parādnieks atzinis bez jebkādiem iebildumiem.

1 Sinaiskis V. Saistību tiesības. Latvijas civiltiesību apskats. Rīga, 1940, 34. lpp.

2 Vērtspapīrošana ir nelikvīda aktīva vai aktīvu grupas un finanšu inženierijas process, pārveidojot to (vai tos) par apgrozības spējīgu nodrošinājumu. Sk.: Galant Chris. What is securitization? Pieejams: https://www.investopedia.com/ask/answers/07/securitization.asp\&prev=search [aplūkots 05.02.2019.].

3 Termins securities tiek lietots dažādās nozīmēs, apzīmējot ar to saistību nodrošinājumus vai prasījumu apliecinājumus plašā nozīmē - ḳīla, galvojums, obligācija, akcija, opcija. Šeit šaurākā nozīmē - finanšu vai investīciju instrumenti, ko izmanto finanšu tirgū. Sk. sīkāk: http://www.businessdictionary.com/ definition/securities.html [aplūkots 05.02. 2019.].

4 TAP - tiesiskās aizsardzības process, ĀTAP - ārpustiesas tiesiskās aizsardzības process.

5 Rīgas pilsētas Vidzemes priekšpilsētas tiesas 03.07.2014. lēmums lietā C30447716, SPC-1/2016. Pieejams: https://manas.tiesas.lv/eTiesasMvc/lv/nolemumi [aplūkots 02.02.2019.]. 
Tiesa apstiprināja SIA “G” TAP, nosaucot viena kreditora SIA “BI” iebildumus par pieṇēmumiem un aizdomām. SIA “BI” no prasītāja, kas bija iesniedzis pieteikumu par 300 tūkstošu eiro bezstrīdus piedziṇu, TAP procesā kḷuva par vienu no kreditoriem lielā konkurencē. Iebildumos pret TAP minētais kreditors SIA "BI" sniedza informāciju, kas l̦āva saprast, ka TAP ierosināšana ir mēǵinājums novērst viņa dotā aizdevuma 300 tūkstošu eiro piedziņu bezstrīdus piespiedu izpildǐšanas kārtībā un ieķīātā nekustamā īpašuma atsavināšanu, šim nolūkam uzrādot fiktīvus kreditorus un mākslīgi izveidotus prasījumus. Viena prasījuma pamatā bija 2005. gadā noslēgts SIA “G” līgums ar personu D par 160 tūkstošu latu aizdevumu, kas ar tiesas lēmumu jau 2006. gada 7. augustā (pirms vairāk nekā 8 gadiem!) nodots bezstrīdus piespiedu izpildīšanai, bet bijis bez kustības. Otrs prasījums SIA “DL S” ar cesiju iegūts prasījums par 5 miljoniem eiro (!!) - izrietot no pavisam neparasta un tiesas vērtējumu pelnoša 2013. gada opcijas pirkuma līguma, kurā izteikta līdzēju apṇemšanās risināt pārdevējam vēl nepiederoša nekustamā ipašuma pārdošanu, ja atkritīs šḳēršli šādai pārdošanai. Tajā 5 miljoni eiro varētu būt uztverami kā līgumsods par līguma nepildīšanu situācijā, kad nav skaidrības par nepildī̌̌anas vaininieku. Minētās summas piedziṇa tikusi noteikta ar zemesgrāmatu tiesneša 2013. gada 6. novembra lēmumu par piespiedu izpildi brīdinājuma kārtībā.

SIA “BI” rakstiskie iebildumi netika ņemti vērā, un TAP plāns tika apstiprināts ar pārliecinošu kreditoru vairākumu. ${ }^{6}$

Savdabīga problēma tika izvirzìta nesen izbeigtajā lietā, kurā norisinājās strīds par milzīga apmēra prasījuma - arī piecu miljonu eiro - divkāršu cesiju.

Sabiedrībai “T” un citiem lidsabiedrības AirBaltic finansētājiem (akcionāriem) saskaņā ar 2011. gada 3. oktobra vienošanos, lai saglabātu sabiedrības stabilitāti, bija jāiegulda noteiktas summas, bet, ja SIA “BAS” kā viens no akcionāriem neizpildītu savus pienākumus, tad visiem vienošanās dalībniekiem (izṇemot valsti) bija jācedē AirBaltic savi naudas prasījumi pret lidsabiedrību. Tā kā BAS neizpildīja savu vienošanos pret valsti un Satiksmes ministrija uz pirmpirkuma tiesību pamata iegādājās AirBaltic mazākuma akcionāram BAS piederošās aviokompānijas kapitāldaḷas, “T” prasījums 3,5 miljonu latu (atbilst 5 miljoniem eiro) apmērā pēc plaša līguma par veicamajiem pasākumiem bija uzskatāms par cedētu aviokompānijai. Taču "T" noslēdza jaunu cesijas līgumu par prasijuma 3,5 miljonu latu apmērā cedēšanu sabiedrībai "E J”. Izvērsās strīds par to, vai pirmā cesija notikusi par labu AirBaltic vai SIA “E J”. Augstākās tiesas Civillietu tiesu palāta 2016. gada oktobrī noraidīja AirBaltic prasību pret "T" un SIA “E J" par 5 miljonu eiro prasījuma atzīšanu par cedētu un nodotu. ${ }^{7}$ Tas radīja draudus, ka cesionārs "E J" varētu vērst prasījumu par šādu summu pret AirBaltic. Lieta nonāca kasācijas instancē. Augstākās tiesas Senāts 2018. gada 5. decembrī atcēla Civillietu tiesu palātas spriedumu un tiesvedību lietā izbeidza, konstatējot, ka nav noticis tiesību aizskārums. ${ }^{8}$

6 Tieslietupadomepublisko ziņojumuparmaksātnespējas procesu tiesvedībuizvērtējumu.27.08.2018. Pieejams: http://www.at.gov.lv/lv/jaunumi/par-tieslietu-padomi/tieslietu-padome-publisko-zinojumu-parmaksatnespejas-procesu-tiesvedibu-izvertejumu-9227? year=2018\&month=8\& [aplūkots 02.02.2019.].

7 Ar jaunu sparu atsākas tiesāšanās par 'airBaltic’ piecu miljonu prasījumu. 24.09.2016. Pieejams: https:// www.google.com/search?q=Noraida+\%27airBaltic\%27+1\%C5\%ABgumu+atz\%C4\%ABt+par+ced\% $\mathrm{C} 4 \% 93 \mathrm{tu}+5+$ miljonu+eiro+pras\%C4\%ABjumu\&oq=.69i57.9052j0j8\&sourceid $=$ chrome\&ie $=\mathrm{UTF}-8$ [aplūkots 02.02.2019.].

8 Augstākās tiesas Senāta 05.12.2018. spriedums lietā (izskatīta slēgtā procesā) Nr. C04305812, SKC$242 / 2018$. 
No civiltiesību teorijas viedokḷ kuriozākais šajā stāstā ir tas, ka nopietnu sabiedrību nopietni advokāti iesniedz tiesai pierādijumus par 5 miljonu eiro cesiju, bet nespēj paskaidrot, uz kāda pamata un kā notikusi vai notiks cesija - vai pretī dodot piecus miljonus skaidrā naudā, vai šie miljoni vienkārši uzdāvināti. Savdabīgi bija arī skaidrojumi, ka pēc cedenta gribas prasījums ir nonācis pie "E J" ātrāk, nekā to iegrāmatot paspēja AirBaltic, tāpēc pēdējai jāsamierinās bez šì prasijuma. Augstākās tiesas Senāts, atzīstot, ka nekāds aizskārums vēl nav noticis, lika saprast, ka divu sabiedrību "savstarpēja parotaḷāšanās ar cesiju" nerada tiesiskās sekas trešajai personai, proti, tai, pret kuru prasijjums var tikt vērsts. Par to gan varētu diskutēt. Taču minētais strīds liek apsvērt, vai cedēta prasījuma atzīšana par īpašuma objektu, kā apgalvots dažās ārvalstu publikācijās, vai pat pielīdzinājums ķ̧ermeniskai lietai, nav kḷūdains. Taču aprakstītais gadijums apstiprina, ka risināms jautājums par prioritātēm, ja prasījums cedēts vairākām personām, kā iezīmēts ES Regulas projektā.

Cesija ir kḷuvusi par instrumentu, ar kura palīdzību tiek mēgināts apgrūtināt nodokḷu parādu piedziṇu vai panākt citus prettiesiskus rezultātus.

Liepājas tiesa 2018. gada 30. janvārī taisīja spriedumu, kurā strīda būtība ir šāda.

SIA AG Limited 2017. gada 17. maijā cēla prasību pret SIA "X"9 par parāda 3690 eiro un tiesas izdevumu piedzinu, apgalvojot, ka 2017. gada 13. martā SIA AG Limited ar cesijas ligumu nopirkusi no SIA Gamma Transports prasijuma tiesības par 3690 eiro pret SIA "X”. Par cesiju 31. martā ierakstītā pasta sūtījumā paziņots parādniecei SIA “X”. Tā kā parādniece parādu nesamaksāja arī pēc atgādinājuma, tika celta prasība tiesā. Atbildētāja paskaidrojumos tiesai norādīja, ka cedenta, SIA Gamma Transports, rīcība, iespējams, liecina par vēlmi izvairīties no nodokḷu parāda piedziṇas, kuru šajā situācijā iespējams veikt, vēršot piedziṇu pret trešajām personām, pie kurām ir parādnieka manta, un ka SIA Gamma Transports nemaz neesot bijušas tiesības cedēt summas, kas pastāvēja kā parāds pret Valsts ieņēmumu dienestu (turpmāk - VID). VID kā trešā persona lietā paskaidroja, ka tā jau bija uzsākusi darbības parāda piedziṇai, taisot 2017. martā lēmumu par nodokḷu parāda 35 887,52 eiro piedziṇu bezstrīdus kārtībā. Arī VID ieskatā cesija liecinot par mēginājumu izvairīties no nodokḷa parāda samaksas. Tiesa atzina, ka SIA AG Limited prasība noraidāma. ${ }^{10}$

Cesija dažkārt praksē tiek veikta pavisam īpatnā veidā, kas izraisa jautājumus par centieniem novirzìt kreditoriem pienākošos naudu citam saṇēmējam. To var ilustrēt ar šādu Augstākajā tiesā izskatītu Prokuratūras protesta lietu.

Ar Rīgas pilsētas Zemgales priekšpilsētas tiesas 2016. gada 5. oktobra spriedumu (civillietā Nr. C31234016) apmierināta maksātnespējīgās SIA (turpmāk MSIA) "Rema kokaudzētavas" administratores prasība pret bijušo sabiedrības valdes locekli [pers. A] par zaudējumu 1059 587,15 eiro piedziṇu. Minētais spriedums stājies likumīgā spēkā 2016. gada 26. oktobrī.

Starp administratori un SIA Gelvora 2017. gada 2. februārī noslēgts cesijas līgums, ar kuru MSIA "Rema kokaudzētavas" nodeva SIA Gelvora savas ar šo spriedumu noteiktās tiesības par zaudejumu 1059 587,15 eiro piedziṇu no parādnieka [pers. A]. Savukārt 2017. gada 13. martā tiesā saṇemts administratores

9 Piezīme: šis SIA nosaukums atšķirībā no citu lietas dalībnieku nosaukumiem ir anonimizēts.

${ }^{10}$ Liepājas tiesas 30.01.2018. spriedums lietā Nr. C-0292-18/6. ECLI:LV:LIET:2018:0130.C20148617.2.S. 
pieteikums par puses procesuālo tiesību pārṇemšanu atbilstoši Civilprocesa likuma 77. pantam.

Ar Rīgas pilsētas Zemgales priekšpilsētas tiesas tiesneša 2017. gada 22. marta lēmumu SIA Gelvora pieteikums par puses procesuālo tiesību pārṇemšanu noraidīts. Tiesa atzina, ka ar cesijas līgumu administratore nodevusi nevis savas tiesības celt prasību pret valdes locekli, kas paredzētas Maksātnespējas likuma $72 .{ }^{1}$ panta trešajā daḷā, bet gan ar tiesas spriedumu iegūtās prasījuma tiesības uz zaudējumu piedziṇu. Prasības pamatā bija sabiedrības bijušās amatpersonas rīcība, kas nodarījusi sabiedrībai zaudējumus. Piespriestā summa pienākas kreditoriem, un šādas ekskluzīvas tiesības nevar nodot citām personām cesijas ceḷā. Taču atklājās, ka SIA "Rema kokaudzētavas" likvidēta 2017. gada 12. aprīlì.

Par šo lēmumu tika iesniegts G̣enerālprokuratūras protests, taču Augstākā tiesa to noraidīja, norādot - no Maksātnespējas likuma 81. panta pirmās daḷas 8. punkta, 113. panta pirmās daḷas 9. punkta un trešās daļas normām izriet, ka administrators ir tiesīgs cedēt maksātnespējīgās komercsabiedrības prasījumu vienīgi tad, ja kreditori, būdami informēti par šādu priekšlikumu, 15 dienu laikā neizteic iebildumus. Netika izvirzìts jautājums par to, vai administratores rīcībā nav saskatāmas noziedzīga nodarījuma pazìmes. ${ }^{11}$

\section{Starptautiskais aspekts}

Rūpes par vienota kapitāla tirgus izveidi mudinājušas Eiropas Komisiju salīdzināt cesijas regulējumu dažādās ES dalībvalstīs un, konstatējot lielas atšķirības, izstrādāt Regulas projektu, kas iespēju robežās sekmētu kolīziju atrisināšanu pārrobežu strīdos par cesijas sekām attiecībā uz trešajām personām.

2016. gada septembrī tika publicēts Komisijas ziņojums Eiropas Parlamentam, Padomei un Eiropas Ekonomikas un sociālo lietu komisijai par tiesiskajām sekām, ko cesija vai subrogācija rada trešajām personām, un par cedēta vai subrogēta prasījuma prioritāti attiecībā pret citu personu tiesībām. ${ }^{12}$ Tajā atzīts, ka pastāv daudzi ilgstoši sarežḡījumi, kas kavē pārrobežu ieguldījumus. Viens šo sarežḡījumu iemesls ir apstāklis, ka valstīs tiek atšḳirīgi vērtētas tiesiskās sekas, ko parādu prasījumu cesija rada trešajām personām; tās apgrūtina šo instrumentu izmantošanu pārrobežu nodrošinājumam, jo īpaši tad, kad banku aizdevumi tiek mobilizēti kā finanšu nodrošinājums centrālo banku kredītoperācijās vai vērtspapīrošanas kontekstā. Turklāt ieguldītājiem ir sarežgìiti novērtēt parāda ieguldījumu riska cenu. Turpinot risināt šos jautājumus, 2018. gada martā tika publicēts projekts (priekšlikums) Regulai par tiesību aktiem, kas piemērojami prasījumu cesijas sekām attiecībā uz trešajām personām. ${ }^{13}$ Regulas veidotāji gan neizvirza mērḳi unificēt normas par cesiju. Tas acìmredzot izraisītu asas argumentu sadursmes starp valstīm, kurās cesijas regulējums ir krasi atšķirīgs. Šajā dokumentā iecerēts nevis aptvert

11 Latvijas Republikas Augstākās tiesas Civillietu departamenta 02.02.2018. lēmums lietā Nr. C31234016, SPC-1/2018. ECLI:LV:AT:2018:0202.C31234016.2.L.

12 Komisijas ziņojums Eiropas Parlamentam, Padomei un Eiropas Ekonomikas un sociālo lietu komisijai par tiesiskajām sekām, ko cesija vai subrogācija rada trešajām personām, un par cedēta vai subrogēta prasījuma prioritāti attiecībā pret citu personu tiesībām. 29.09.2016. COM(2016) 626 final.

13 Priekšlikums Regulai par tiesību aktiem, kas piemērojami prasījumu cesijas sekām attiecībā uz trešajām personām. Brisele, 12.03.2018. COM(2018) 96 final 2018/0044(COD). Pieejams: https://eur-lex.europa. eu/legal-content/LV/TXT/?uri=CELEX:52018PC0096\&qid=1546800517080 [aplūkots 20.02.2019.]. 
visus ar cesiju saistītos jautājumus, bet radīt tikai vienotas tiesību kolīziju normas specifiski cesijas ietekmei uz trešajām personām, kas netika izdarīts, gatavojot Regulu Roma I. Regulas projekta 4. pantā ietvertā nostādne ir tāda, ka prasījumu cesijas radītās sekas attiecībā uz trešajām personām reglamentē tās valsts tiesību akti, kurā atrodas cedenta pastāvīgā mìtnesvieta būtisko apstākḷu rašanās brīdī. Seko gan atrunas, ka iespējami arī citādi risinājumi.

Tādējādi ir būtiski apsvērt jautājumu par to, vai gadījumā, ja Latvija konkrētā pārrobežu konfliktā kḷūst par valsti, pēc kuras likumiem nosakāmas cesijas sekas attiecībā uz kādas trešās personas mantiskajām interesēm, mūsu likums dod skaidras atbildes uz šādiem jautājumiem:

- par bezatlīdzības cesijas piel̦aujamību un robežām;

- par izṇēmumiem, kad cesija veicama rakstiskā formā;

- par izṇēmumiem, kad nosakāma cesijas reǵistrācija.

- par prioritāti, ja prasījums cedēts vairākas reizes;

- kā rīkoties, ja cedēts nedrošs, nosacīts vai nākotnes prasījums, kura apmēru nav tiesa vērtējusi.

Mēginot izvērtēt, vai CL vai kāds cits Latvijas likums dod skaidrību par sekām, ko trešajām personām rada prasījumu cesijas par a) kredītiestādes kontā kreditētas skaidras naudas līdzekḷiem un b) prasījumiem, kas izriet no finanšu instrumenta, jākonstatē, ka pietiekamas skaidrības nav. Piemēram, banka droši vien atteiktos pārformēt kādas personas kontu uz citas vārdu, ja pēdējā uzrādītu vienkāršas formas cesijas lïgumu.

\section{Esošais regulējums un tā vājās vietas}

Latvijas Civillikumā nodaḷa par cesiju izvietota Saistību tiesību daḷā atsevišķi no citu līgumu speciālā regulējuma, var teikt - šìs dal̦as vispārējo noteikumu daḷā, ar to nostiprinot, ka cesija var notikt gan jebkura lìguma radìta prasījuma gadījumā, gan arī pēc likuma un tiesas sprieduma (CL 1793. p.). Ja cesijas pamatā ir līgums, tad to nevar uzskatìt par tādu, kas ir svarīgāks vai stiprāks par citiem līgumiem. Taču īpaši atzīmējams tas, ka prasījums, kas tiek cedēts, parasti ir radies uz kāda cita līguma (pirkuma, dāvinājuma, aizdevuma u. c.) pamata. Lìgumiskajā cesijā Civillikumā nav noteikts pienākums kaut kādā veidā raksturot cedējamā prasījuma izcelsmi un juridisko dabu, piemēram, vai prasījums radies atlīdzības vai bezatlīdzības darījumā.

Ir svarīgi nošķirt pamatlīgumu kā mantisku saistību izpildes pamatu no cesijas kā cesionāra gribas izpauduma par izpildījuma saņēmēja nomaiņu, kas ietverta cesijas līgumā, bieži vien neatklājot, kāda ir gribas izpauduma causa, vai cesija ir par atlīdzību vai bez atlīdzības.

Latvijas juridiskajā literatūrā nav analizēts jautājums par to, vai cesijas līgums ir kauzāls vai abstrakts (no pamata atvilkts) darījums. Šāda jautājuma apskats ir vēlams tāpēc, ka no atbildes atkarīgs, vai cesijas gadījumā no cedenta var prasīt pamatojumu cesijas veikšanai un vai tiesai jāpārbauda kādas puses apgalvojumi, ka darījums varētu būt fiktīvs vai neatbilstošs normālai komercpraksei. Promocijas darbu par cesiju 2015. gadā ir aizstāvējusi Vita Nemenova. ${ }^{14}$ Viṇas darbā ir

${ }^{14}$ Nemenova V. Cesijas tiesiskā regulējuma modernizācijas virzieni Latvijā. Promocijas darbs tiesību doktora zinātniskā grāda iegūšanai. Rīga, 2015. Pieejams: https://www.rsu.lv/sites/default/files/dissertations/Vita_Nemenova_promocijas_darbs.pdf [aplūkots 19.02.2019.]. 
atzīmēts, ka germāṇu civiltiesību zinātnes pārstāvju vidū valda viedoklis par cesijas līguma abstrakto dabu. Austrijas civiltiesību zinātnē šis līgums tradicionāli tiek raksturots kā kauzāls darījums. Šveices civiltiesību zinātṇu pārstāvju vidū jautājums par cesijas abstrakto vai kauzālo dabu ir strīdīgs. ${ }^{15}$ Apgalvojums, ka cesijas līgums ir abstrakts darījums, izteikts arī Latvijas juridiskajā literatūrā, diemžēl visai pretrunīgi. ${ }^{16}$ Analīzes pamatojumā ir teorija par darījumu dalījumu rīcības un apņemšanās darījumos. Cesijas līgums kā rīcības darījums esot abstrakts darījums, jo no tā nav redzams prasijuma pārejas tiesiskais pamats, piemēram, dāvinājuma līgums. ${ }^{17}$ Taču turpat, atsaucoties uz Vācijas tiesību izpratni, ir apgalvots, ka abstrakti ir vairums rīcības darijumu, bet to tiesiskais pamats, kas neietilpst darījuma saturā, vienmēr ir kāds kauzāls apņemšanās darījums. Kaspars Balodis raksta, ka piešķīrumam vienmēr ir kāds tiesisks pamats (lat. val. - causa), kas juridiski attaisno piešķ̄iruma izdarīšanu. ${ }^{18}$ Jāpiebilst gan, ka pieškīiruma tiesiskumu var pārbaudīt un apšaubìt. Saistību līgumi esot kauzāli līgumi. Tātad dalījums abstraktos un kauzālos līgumos ir skatìts citādā aspektā, nekā tiek runāts par pamata atvilktību vekseḷa vai čeka izdošanas darījumā. Ir skaidrs, ka cesijas līgumam jāpiemēro vispārējais noteikums, ka līguma noslēgšanas pamatu var meklēt un vērtēt, tostarp atzìt, ka pamats (lat. val. - causa cessionis) ir samākslots vai fiktīvs. Nevar piekrist V. Nemenovas apgalvojumam, ka Latvijas likumdevējs konstruē cesijas līgumu kā abstraktu rīcības darījumu. ${ }^{19}$

Daži citi apgalvojumi, piemēram, ka cesija ir kauzāls darījums tāpēc, ka tās pamats ir vai nu līgums, likums vai testaments, arī parāda, ka cesijas pamata esību var raksturot šādā plašā nozīmē un atrauti no apskatāmā jautājuma par cesijas isstumu un patiesajiem mērḳiem. ${ }^{20}$

Tas, ka Civillikumā nav nekādu norāžu par nepieciešamu pamatojumu, kāpēc puses slēdz cesijas līgumu, nav atzīstams par argumentu secinājumam, ka darījums pieskaitāms pie abstraktajiem. Cedentam var būt dažādi motīvi, kāpēc viṇš izlemj atteikties no prasījuma apmierinājuma un pārcel̦ savas tiesības uz citu personu ar cesijas līgumu. Tiesu praksē šim jautājumam netiek veltīta īpaša uzmanība, tas skaitās līdzēju autonomijas jeb līgumu brīvības jautājums. Taču, ja kāda persona cedē prasījumu par, piemēram, 5 miljoniem eiro, tad nozīmīgs ir jautājums, vai tas noticis par samaksu vai bez atlīdzības. Ja bez atlīdzības, tad kāds cits pamats var būt piecu miljonu dāvinājumam.

\footnotetext{
15 Nemenova V. 2015, 82. lpp.

16 Kalniņš E. Tiesisks darījums. Grām.: Privāttiesību teorija un prakse. Raksti privāttiesībās. Rīga: Tiesu namu aǵentūra, 2005, 146. lpp.; Balodis K. Ievads civiltiesībās. Rīga: Zvaigzne ABC, [b. g.], 175. lpp.

19 Nemenova V. 2015, 82. lpp.

20 Sk., piemēram: http://www.kasaroglu.av.tr/en/28605/What-Is-Voluntary-Assignment-Transfer-ofClaim
} 


\section{Par Latvijas likumu pilnveidošanu}

Pirmais uzlabojums būtu vēršams uz cesijas līgumu sadalīšanu divās grupās, par paraugu ņemot Kopējā modelī²1 piedāvāto dalījumu. Kopējā modeḷa III grāmatas 5:110 pantā ir noteikts, ka uz cesijas līgumu attiecināmi attiecīgi noteikumi par līgumu formēšanu un spēku, nodalot divas grupas: ja cesija ir bezatlīdzības darijums, tad piemērojami IV grāmatas $\mathrm{H}$ nodal̦as noteikumi par bezatlīdzības aktiem, un, ja cesija ir vērtspapīrošanas mērķim, tad piemērojami IX grāmatas noteikumi. Minētajās IV un IX grāmatās gan nav izvērsts īpatnību regulējums, taču nav šaubu, ka pastāv būtiskas atškiriības starp nosauktajām grupām un dalījuma fiksēšana likumā veicinātu attiecīgas prakses veidošanu.

UNIDROIT principos nav tāda dalījuma, taču atspoguḷojas iespējamība, ka var būt cesija nodrošinājumam (nodrošinājuma vajadzībām). Tas nozīmē, ka bankas kredīta dzēěanas nodrošinājumam var cedēt visus prasijumus, kādi radīsies komersantam, kurš apkalpo lielu skaitu klientu. Tas atgādina blanko cesiju un kaut ko līdzīgu visas mantas ieķīāšsanai komercķillas veidā, tāpēc arī apdomājams jautājums par tādas reǵistrēšanu Uzṇēmumu reg̣istrā vai citādi. Jāizstrādā arī risinājumi, lai nekonkurētu ar komerckīiām.

Maldinošs ir CL 1801. panta noteikums, ka cesijas līgumu var noslēgt jebkādā formā. Būtu vajadzīga prasību noteikšana attiecībā uz cesijas rakstveida formu, kā arī gadījumiem, kad cesija reg̣istrējama vai citādi padarāma publiski nostiprināma. Tādas prasības varētu mazināt apgrozības ātrumu un cesijas piemērojamību finanšu tirgū un citur biznesā, taču dotu lielāku drošỉbu un tiesisko pal̦āvību. Tāpēc nosakāmi arī izṇēmumi.

Atlīdzības jautājums līdzšinējā praksē nav bijis tiesu noskaidrošanas priekšmets, kā būtisks uzsvērts fakts, ka CL piẹ̦auj gan bezatlīdzības, gan atlīdzības cesiju. Taču, analizējot vairāku "skaļu" lietu materiālus, jautājums par atlīdzību iegūst būtisku svaru. Bezatlīdzības darījumi komercattiecībās nav tipiski, tie neatbilst komercdarbības būtībai. Nebūtu vajadzīgs aizliegt ziedot, sponsorēt, bet tad mērḳim jātiek atklātam un summai jābūt adekvātai labdarībai. Līdz ar to tiek izvirzìts ierosinājums Komerclikumā ietvert normu: "Bezatlīdzības cesija komersantu darijumos nav atḷauta, izñemot saprātīgas labdarības gadỉjumus.”

Lai pieskaņotos saistību dalībnieku maiñas regulējumam, kas veidots saskan̄ā ar Regulu Roma I, iepriekš minēto regulas projektu, kā arī UNIDROIT starptautisko komerclīgumu principiem, - būtu lietderīgi Latvijas likumos ietvert subrogāciju, vismaz jēdziena izpratnes līmenī nosakot šì tiesību institūta sakaru ar pārjaunojumu un atšķirību no cesijas. Latvijas civiltiesību teorijā subrogācija ir pazīstama, piemēram, kā Regulā Roma I lietots termins. Regulā likumiskā subrogācija definēta kā personu maiņa gadījumos, kad trešajai personai ir pienākums apmierināt kreditora prasijumu pret parādnieku vai viņa, izpildot attiecīgu pienākumu, faktiski ir apmierinājusi kreditora prasijumu. Tad šai personai rodas regresa prasījums pret parādnieku, un tā pamatu dažās valstīs kvalificē kā cesiju, bet citās - kā subrogāciju. ${ }^{22}$ Nav īstas skaidrības par to, kādā apmērā viens

${ }^{21}$ Principles, Definitions and Model Rules of European Private Law. Draft Common Frame of Reference. Pieejams: https://zodml.org/sites/default/files/Principles\%2C_Definitions_and_Model_Rules_of_ European_Private_Law_Draft_Common_Frame_of_Reference_\%28DCFR\%29\%2C_Outline_ Edition.pdf [aplūkots 26.02.2019.].

22 Sk.: Mantrovs V. Apdrošināšanas tiesības. Rīga: LU Akadēmiskais apgāds, 2018, 282. lpp. 
subjekts - parādnieks - tiek aizstāts ar citu. Procesuālās tiesības vērsties ar regresa prasību var izrādīties iluzoras materiālo tiesību aspektā. Juridiskajā literatūrā izteikts viedoklis, ka subrogācijā jaunais tiesiskās attiecības dalībnieks pilnībā aizstāj agrāko, atšķirībā no cesijas, kurā uz cesionāru pāriet tikai prasījuma tiesība, bet ne tā līgumiskā attiecība, no kuras šì tiesība izriet (CL 1800. p.). Taču Vadima Mantrova skaidrojums, ka apdrošināšanā uz apdrošinātāju subrogācijas cel̦ā pāriet cietušā prasījuma tiesības pret apdrošināšanas gadījuma izraisītāju, ir diskutabls, jo apdrošinātājam pašam ir saistỉba samaksāt apdrošināšanas atlīdzību, un vairumā gadījumu pamats ir nejaušîba, nevis kādas personas prettiesiska rīcība. ${ }^{23}$ Zīmīga ir arī tāda īpatnība, ka par subrogācijas pamatu atzīst ne tikai vienošanos, bet arī kāda pienākuma faktisko izpildī̌anu citas personas vietā, kā tas notiek, apdrošinātājam samaksājot apdrošināšanas atlīdzību par kāda cita radītu kaitējumu. Taču dažādu valstu likumu skaidrojumos ir pausti atšķirīgi viedokḷi par to, kādā apjomā notiek šì tiesību subjektu maiņa, kas regulas projektā formulēta normatīvam aktam netipiskā veidā, kā iekāpšana cita kurpēs (angḷu val. - to step into shoes of debtor). Nìderlandes Civilkodeksa 6.2.2. sekcijā nosaukti četri subrogācijas pamati, kā arī noteikti subrogācijas ierobežojumi un iespējamie savstarpējie norēķini (6:150.-6:152). ${ }^{24}$ Latvija jau kopš CL pastāvēšanas ir demonstrējusi, ka var itin labi iztikt bez subrogācijas iekḷaušanas likumā. Tas nenozīmē, ka šis tiesību institūts nebūtu jāpazīst teorijā, bet iekḷaušanai likumā vajadzīga plašāka izpēte.

\section{Kopsavilkums}

1. Latvijas Civillikumā cesijas regulējums ir saglabājies nemainīts kopš 1937. gada un vairs neatbilst tās piemērošanas daudzveidīgumam, it sevišķi vērtspapīrošanas un investīciju darījumos.

2. Eiropas Savienības institūcijas, piedāvājot regulas projektu, nav izvirzijjušas mērķi unificēt cesijas un subrogācijas piemērošanu kopumā. Tāpēc tās pilnveidošana jāveic dalībvalstīm nacionālajos likumos. Lai tuvinātos citu ES dalībvalstu tiesību sistēmām, subrogāciju kā tiesību institūtu vēlams atzìt Latvijas likumā, rūpīgi izsverot tās vietu tiesību sistēmā.

3. Lìgumiskā cesija nav abstrakts, no darījuma pamata atvilkts darījums. Strīda gadijumā tās pamats pārbaudāms tiesā.

4. Bezatlīdzības cesija komersantu darījumos piẹ̦aujama vienīgi saprātīgas labdarības ietvaros.

5. Nepieciešams risināt jautājumu par cesijas rakstiskas formas un noteiktos gadījumos arī registrācijas noteikšanu, diferencējot dažādos cesijas veidus pēc to nozīmes civiltiesiskajā apgrozībā un cedējamā prasījuma apmēra.

${ }^{23}$ Mantrovs V. Regresa prasības regulējums Latvijas apdrošināšanas tiesībās. Grām.: Ārvalsts investīcijas: kad tiesības mijiedarbojas. Latvijas Universitātes 74. zinātniskās konferences rakstu krājums. Rīga: LU Akadēmiskais apgāds, 2016, 408.-419. lpp.

${ }^{24}$ Dutch Civil Code. Section 6.2.2. Subrogation. Pieejams: http://dutchcivillaw.com/legislation/indexb66. htm [aplūkots 20.02.2019.]. 